\title{
PROFIL PNEUMONIA NEONATUS YANG DIRAWAT DI RSUP PROF. Dr. R. D. KANDOU MANADO
}

\author{
${ }^{1}$ Juhtisari Jufri \\ ${ }^{2}$ Audrey Wahani \\ ${ }^{3}$ Rocky Wilar
Bagian Ilmu Kesehatan Anak RSUP Prof. Dr. R. D. Kandou Manado
Email : jiejie_meonk@yahoo.co.id

\begin{abstract}
Abstrack: Background : Pneumonia is an important cause of neonatal infection. Neonatal mortality rate in pneumonia ranged from 750,000 to 1.2 million deaths and the number of deaths is unknown at birth each year. Methods : This study uses a retrospective descriptive. Results : $95.31 \%$ occurred in the age group 0-7 days. $85.94 \%$ with normal leukocyte levels. $54.69 \%$ trombist normal levels. $40.62 \%$ increase hemoglobin levels. On examination CRP increased $67.86 \% .54 .69 \%$ IT ratio $<0.2 .96 .87 \%$ with clinical symptoms of tachypnea. $45.83 \%$ using the first linea (amoxycillin + gentamicin). $53.12 \%$ of patients were healed with the state.

Conclusions : Neonatal pneumonia is most prevalent in early onset (0-7 days). Normal leukocytes are most found. While the platelets also found in most normal limits. The hemoglobin most commonly found an increase. Examination results are most CRP increased. Furthermore, the examination and the ratio of immature neutrophils total (IT ratio) is most commonly found <0.2. Tachypnea is the most clinical symptoms found. Patients with pneumonia were cured many neonates using the first linea treatment combinations (amoxycillin + gentasmisin). Mortality rates were obtained from neonates suffering from pneumonia at $4.69 \%$.
\end{abstract}

Key words : Pneumonia, neonates.

Abstrak: Latar Belakang : Pneumonia merupakan penyebab penting infeksi neonatal. Angka kematian neonatal pada penyakit pneumonia berkisar antara 750.000 sampai 1,2 juta kematian dan jumlah kematian saat dilahirkan tidak diketahui setiap tahunnya. Metode : Penelitian ini menggunakan metode deskriptif retrospektif. Hasil : 95,31\% terjadi pada kelompok umur $0-7$ hari. 85,94 \% dengan kadar leukosit normal. 54,69 \% kadar trombist normal. 40,62 \% kadar hemoglobin meningkat. Pada pemeriksaan CRP 67,86 \% meningkat. 54,69 \% IT Rasionya <0,2. $96,87 \%$ dengan gejala klinis takipnea. 45,83 \% menggunakan linea pertama (amoxycillin+gentamisin). 53,12\% dengan keadaan penderita yang sembuh. Kesimpulan : Pneumonia neonatus paling banyak ditemukan pada onset awal (0-7 hari). Leukosit ditemukan paling banyak normal. Sementara trombosit juga ditemukan paling banyak dalam batas normal. Hemoglobin paling banyak ditemukan adanya peningkatan. Pemeriksaan CRP hasilnya paling banyak mengalami peningkatan. Selanjutnya pada pemeriksaan Rasio imatur dan neutrofil total (Rasio IT) yang paling banyak ditemukan $<0,2$. Takipnea merupakan gejala klinis yang paling banyak ditemukan. Penderita pneumonia neonatus banyak yang sembuh dengan menggunakan pengobatan linea pertama kombinasi (amoxycillin+gentasmisin). Angka kematian yang didapatkan dari neonatus yang menderita pneumonia sebesar 4,69\%.

Kata Kunci : Pneumonia, neonatus. 
Penyakit infeksi masih merupakan penyakit utama dibanyak negara berkembang, termasuk Indonesia. Jenis penyakit infeksi di Indonesia yang banyak diderita adalah infeksi saluran napas akut (ISPA), baik ISPA bagian atas misalnya batuk, pilek, faringitis maupun ISPA bagian bawah seperti bronkitis dan pneumonia. ${ }^{1}$ Infeksi saluran napas akut (ISPA) merupakan penyebab terpenting morbiditas dan mortalitas pada anak. ${ }^{2}$

Pneumonia adalah inflamasi yang mengenai parenkim paru. Sebagian besar disebabkan oleh mikroorganisme (virus/bakteri) dan sebagian kecil disebabkan oleh hal lain (aspirasi, radiasi, dll). ${ }^{3}$ Pneumonia pada anak merupakan infeksi yang serius dan banyak diderita pada anak-anak diseluruh dunia. ${ }^{4}$

Pneumonia merupakan penyebab penting infeksi neonatal dan untuk angka morbiditas dan mortalitas yang signifikan, pada periode neonatal. ${ }^{5}$ Pneumonia neonatal adalah infeksi paru-paru pada neonatus. ${ }^{6}$ Dengan menyajikan gambaran klinis dari gangguan pernapasan, terkait dengan temuan radiologi dada menunjukkan pneumonia dan bertahan selama minimal 48 jam. ${ }^{7}$ Onset bisa terjadi pada saat lahir dan bagian dari sindrom sepsis atau setelah 7 hari dan terbatas pada paru-paru. ${ }^{6}$

Di negara-negara, Organisasi Kesehatan Dunia (WHO) memperkirakan bahwa hampir 800.000 kematian neonatal terjadi setiap tahun akibat infeksi pernapasan akut, sebagian besar pneumonia. ${ }^{8}$ Kematian yang terjadi pada periode neonatal setiap tahun mencapai $41 \%$ (3,6 juta) dari semua kematian pada anak di bawah 5 tahun. ${ }^{9}$

Angka kematian neonatal pada penyakit pneumonia berkisar antara 750.000 sampai 1,2 juta kematian dan jumlah kematian saat dilahirkan tidak diketahui setiap tahunnya. Diperkirakan bahwa 3,9 juta dari 10,8 juta kematian pada anak-anak setiap tahunnya di seluruh dunia terjadi pada 28 hari pertama kehidupan. Lebih dari $96 \%$ dari semua kematian neonatal terjadi di negara berkembang. ${ }^{10}$

Pneumonia pada neonatus sering terjadi akibat transmisi vertikal ibu-anak yang berhubungan dengan proses persalinan. Infeksi terjadi akibat kontaminasi dengan sumber infeksi dari ibu, misalnya melalui aspirasi mekonium, cairan amnion, atau dari serviks ibu. Infeksi dapat berasal dari kontaminasi dengan sumber infeksi dari RS (hospitalacquired pneumonia), misalnya dari perawat, dokter, atau pasien lain; atau dari alat kedokteran, misalnya penggunaan ventilator. Disamping itu, infeksi dapat terjadi akibat kontaminasi dengan sumber infeksi dari masyarakat (communityacquired pneumonia). ${ }^{11}$

Pada neonatus gejala dan tanda pneumonia lebih beragam, gejala dan tanda pneumonia tidak selalu jelas terlihat. Gambaran klinis pneumonia neonatus tidak khas, mencakup serangan apnea, sianosis, merintih, napas cuping hidung, takipnea, letargi, muntah, tidak mau minum, takikardi atau bradikardi, retraksi subkosta, dan demam. ${ }^{12}$

Berdasarkan uraian latar belakang di atas peneliti tertarik untuk mengetahui profil penderita pneumonia neonatus yang dirawat di Sub Bagian Neonatologi RSUP Prof. Dr. R. D. Kandou Manado.

\section{METODOLIGI PENELITIAN}

Jenis penelitian yang dilakukan adalah deskriptif retrospektif. Penelitian dilaksanakan di bagian Ilmu Kesehatan Anak RSUP Prof. Dr. R. D. Kandou Manado. Penelitian ini dilakukan selama November-Desember 2012. Populasi penelitian ialah semua neonatus yang dirawat inap di Sub Bagian Neonatologi RSUP Prof. Dr. R. D. Kandou Manado periode Oktober 2010-September 2012. Sampel penelitian ialah Semua data penderita yang didiagnosa menderita pneumonia neonatus yang menjalani rawat 
inap di Sub Bagian Neonatologi RSUP Prof. Dr. R. D. Kandou Manado periode Oktober 2010-September 2012. Kriteria Inklusi ialah neonatus yang menderita pneumonia periode Oktober 2010September 2012 dan neonatus yang lahir dengan usia gestasi 37-42 minggu (aterm). Kriteria Eksklusi ialah kelainan bawaan dan meningitis. Variabel Penelitian yaitu usia, pemeriksaan leukosit, pemeriksaan trombosit, pemeriksaan hemoglobin $(\mathrm{Hb})$, pemeriksaan CRP, IT ratio, gejala klinis, pengobatan, keadaan penderita.

\section{HASIL PENELITIAN}

Berdasarkan hasil pengumpulan data yang dilakukan secara retrospektif dibagian rekam medik RSUP Prof. Dr. R. D. Kandou Manado tentang pasien pneumonia neonatus yang dirawat inap di Sub Bagian Neonatologi pada periode Oktober 2010 - September 2012, tercatat jumlah kasus yang terdiagnosis pneumonia neonatus sebanyak 326 kasus. Namun dalam penelitian ini hanya dibahas 64 kasus saja, karena memenuhi kriteria inklusi.

Tabel 1. Distribusi Penderita Pneumonia Neonatus Berdasarkan Kelompok Usia

\begin{tabular}{llll}
\hline & Variabel Penelitian & Jumlah & Persentase (\%) \\
\hline Usia & $0-7$ hari & 61 & 95,31 \\
& $8-28$ hari & 3 & 4,69 \\
& & & 100 \\
\hline Jumlah & 64 & 100 \\
\hline
\end{tabular}

Pada tabel 1 di atas, didapati bahwa pada kasus pneumonia neonatus paling banyak terdapat pada kelompok usia 0 - 7 hari, yaitu 61 kasus $(95,31 \%)$. Sedangkan sisanya terdapat pada kelompok usia 8-28 hari, yaitu 3 kasus $(4,69 \%)$.

Tabel 2. Distribusi Penderita Pneumonia Neonatus Berdasarkan Pemeriksaan Leukosit

\begin{tabular}{llll}
\hline & Variabel Penelitian & Jumlah & Persentase (\%) \\
\hline Pemeriksaan Leukosit & Meningkat & 9 & 14,06 \\
& Menurun & - & - \\
& Normal & 55 & 85,94 \\
\hline Jumlah & & 64 & 100 \\
\hline
\end{tabular}

Pada tabel 2 di atas, didapatkan bahwa yang mengalami peningkatan pada pemeriksaan leukosit yaitu 9 kasus (14,06\%), yang normal yaitu 55 kasus $(85,94 \%)$. Sedangkan untuk kadar leukosit yang menurun tidak didapatkan pada pasien dengan pneumonia neonatus.

Tabel 3. Distribusi Penderita Pneumonia Neonatus Berdasarkan Pemeriksaan Trombosit

\begin{tabular}{llll}
\hline & Variabel Penelitian & Jumlah & Persentase (\%) \\
\hline Pemeriksaan Trombosit & Meningkat & 3 & 4,68 \\
& Menurun & 26 & 40,63 \\
& Normal & 35 & 54,69 \\
\hline Jumlah & & 64 & 100 \\
\hline
\end{tabular}


Pada tabel 3 di atas, didapatkan bahwa yang mengalami peningkatan pada pemeriksaan trombosit yaitu 3 kasus (4,68\%), yang menurun 26 kasus (40,63\%), sedangkan yang normal yaitu 35 kasus $(54,69 \%)$.

Tabel 4. Distribusi Penderita Pneumonia Berdasarkan Pemeriksaan Hemoglobin (Hb)

\begin{tabular}{llll}
\hline & Variabel Penelitian & Jumlah & Persentase (\%) \\
\hline Pemeriksaan Hemoglobin & Meningkat & 26 & 40,62 \\
& Menurun & 15 & 23,44 \\
& Normal & 23 & 35,94 \\
\hline Jumlah & & 64 & 100 \\
\hline
\end{tabular}

Pada tabel 4 di atas, didapatkan bahwa yang mengalami peningkatan pada pemeriksaan hemoglobin yaitu 26 kasus (40,62\%), yang menurun 15 kasus $(23,44 \%)$, sedangkan yang normal yaitu 23 kasus $(35,94 \%)$.

Tabel 5. Distribusi Penderita Pneumonia Neonatus Berdasarkan Pemeriksaan CRP

\begin{tabular}{llll}
\hline & Variabel Penelitian & Jumlah & Persentase (\%) \\
\hline Pemeriksaan CRP & Meningkat & 19 & 67,86 \\
& Normal & 9 & 32,14 \\
\hline Jumlah & & 28 & 100 \\
\hline
\end{tabular}

Pada tabel 5 di atas, didapatkan bahwa yang mengalami peningkatan pada pemeriksaan CRP yaitu 19 kasus $(67,86 \%)$, sedangkan yang normal yaitu 9 kasus $(32,14 \%)$.

Tabel 6. Distribusi Penderita Pneumonia Neonatus Berdasarkan IT Rasio

\begin{tabular}{llll}
\hline & Variabel Penelitian & Jumlah & Persentase (\%) \\
\hline IT Rasio & $>0,2$ & 29 & 45,31 \\
& $<0,2$ & 35 & 54,69 \\
\hline Jumlah & & 64 & 100 \\
\hline
\end{tabular}

Pada tabel 6 di atas, terlihat hasil dari IT rasio yang >0,2 yaitu 29 (45,31\%), sedangkan yang <0,2 yaitu $35(54,69 \%)$.

Tabel 7. Distribusi Berdasarkan Gejala Klinis

\begin{tabular}{lll}
\hline Gejala Klinis & Jumlah & $\%$ \\
\hline Takipnea & 62 & 96,87 \\
Napas cuping hidung & 52 & 81,25 \\
Demam & 37 & 57,81 \\
Sianosis & 2 & 3,12 \\
Perut kembung & 5 & 7,81 \\
Letargi & 56 & 87,5 \\
\hline
\end{tabular}




\begin{tabular}{lll}
\hline Apnea & 3 & 4,69 \\
Takikardia & 12 & 18,75 \\
Retraksi & 35 & 54,68 \\
\hline
\end{tabular}

Pada tabel 7 di atas, terlhat bahwa takipnea adalah gejala klinis yang paling banyak ditemukan, yaitu sebanyak 62 kasus $(96,87 \%)$, lalu diikuti dengan napas cuping hidung sebanyak $52(81,25 \%)$, demam $37(57,81 \%)$, sianosis $2(3,12 \%)$, perut kembung $5(7,81 \%)$, letargi $56(87,5 \%)$, apnea $3(4,69 \%)$, takikardia 12 (18,75\%), sedangkan retraksi $35(54,68 \%)$.

Tabel 8. Distribusi Penderita Pneumonia Neonatus Berdasarkan Pengobatan Pasien yang Sembuh

\begin{tabular}{|c|c|c|c|}
\hline Pengobatan & Variabel Penelitian & Jumlah & Persentase $(\%)$ \\
\hline Linea Pertama & Amoxycillin+Gentamisin & 11 & 45,83 \\
\hline Linea Kedua & Ceftazidime+Amikasin & 8 & 33,33 \\
\hline Linea ketiga & Meropenem & 1 & 4,17 \\
\hline $\begin{array}{l}\text { Pengobatan lain } \\
\text { (kombinasi masing- } \\
\text { masing obat linea I \& II) }\end{array}$ & Ceftazidime+Gentamisin & 4 & 16,67 \\
\hline Jumlah & & 24 & 100 \\
\hline
\end{tabular}

Pada tabel 8 di atas, terlihat bahwa dari hasil data yang didapatkan untuk pengobatan pasien yang sembuh dengan menggunakan linea pertama kombinasi amoxycillin+gentamisin yang paling banyak digunakan, yaitu sebanyak 11 (45,83\%), untuk linea kedua kombinasi ceftazidime+amikasin terdapat $8(33,33 \%)$, sedangkan linea ketiga (meropenem) yang paling sedikit digunakan, yaitu 1 (4,17\%). Dan juga ada pengobatan lain yaitu kombinasi dari masing-masing linea I dan linea II (ceftazidime+gentamisin) dengan jumlah 4 kasus $(16,67 \%)$.

Tabel 9. Distribusi Berdasarkan Keadaan Penderita

\begin{tabular}{lll}
\hline Keadaan Penderita & Jumlah & Persentase (\%) \\
\hline Sembuh & 34 & 53,12 \\
Belum sembuh & 27 & 42,19 \\
Meninggal & 3 & 4,69 \\
\hline Jumlah & 64 & 100 \\
\hline
\end{tabular}

Pada tabel 9 di atas menunjukkan bahwa berdasarkan distribusi keadaan penderita, diperoleh keadaan penderita yang sembuh terdapat 34 kasus $(53,12 \%)$, dengan keadaan yang belum sembuh yaitu 27 kasus $(42,19 \%)$, dan dengan keadaan meninggal yaitu 3 kasus $(4,69 \%)$.

\section{PEMBAHASAN}

Dari hasil pengumpulan data yang dilakukan dibagian rekam medik BLU
RSUP Prof. Dr. R. D. Kandou Manado yang dirawat inap dibagian Sub Neonatologi, ditemukan bahwa neonatus 
yang menderita pneumonia periode Okteober 2010 - September 2012 yaitu 326 kasus. Namun, dari 326 kasus tersebut, sampel yang diambil hanya 64 kasus saja karena memiliki data yang lengkap dan memenuhi kriteria inklusi dalam penelitian ini.

Berdasarkan distribusi menurut kelompok usia, didapatkan dimana kelompok usia 0 - 7 hari yang terbanyak yaitu 61 kasus $(95,31 \%)$, dan kelompok usia 8 - 28 hari terdapat 3 kasus $(4,69 \%)$. Hasil dari penelitian ini sama dengan penelitian yang dilakukan oleh IB. Mahendra dkk, dalam penelitiannya menemukan kejadian pneumonia neonatal pada onset awal (0-7 hari) lebih besar daripada yang terjadi pada onset akhir (828 hari). Hal ini di karenakan faktor resikonya yaitu ketuban pecah dini $>12$ jam, cairan amnion keruh, suhu tubuh ibu $>38^{0} \mathrm{C}$, infeksi saluran kemih pada ibu, perawatan antenatal yang buruk dan asupan makanan yang buruk dari ibu. ${ }^{13}$

Peningkatan jumlah leukosit menunjukkan adanya proses infeksi, sehingga untuk mendiagnosis suatu infeksi pada pneumonia neonatus perlu dilakukan pemeriksaan leukosit. Dari 64 kasus pneumonia neonatus, terdapat 9 kasus $(14,06 \%)$ yang mengalami peningkatan leukosit. Sedangkan sisanya 55 kasus $(85,94 \%)$ dalam kadar leukosit yang normal, dan dari data yang didapatkan tidak ditemukan penurunan leukosit. Sesuai dengan kepustakaan, yang mengatakan pada pneumonia virus dan mikoplasma ditemukan leukosit dalam batas normal atau sedikit meningkat. ${ }^{11}$

Pada tabel 3, terlihat bahwa trombosit dengan kadar normal yang paling banyak ditemukan yaitu 35 kasus (54,69\%), sementara 26 kasus $(40,63 \%)$ kadar trombositnya menurun dan yang mengalami peningkatan yaitu 3 kasus $(4,68 \%)$, Berdasarkan kepustakaan yang ada, penyebab paling sering pada trombosit yang menurun (trombositopenia) adalah ibu dengan pre-eklampsia dan diabetes mellitus, pertumbuhan janin terhambat, dan sepsis neonatal. ${ }^{14}$

Hemoglobin mempunyai peran sangat penting sebagai pengikat oksigen di dalam darah. Dari hasil data yang didapatkan, terdapat 26 kasus $(40,62 \%)$ yang mengalami peningkatan hemoglobin, sedangkan 15 kasus $(23,44 \%)$ kadar hemoglobinnya menurun. Sisanya 23 kasus $(35,94 \%)$ normal. Menurut penelitian F. Guven, dkk, didapatkan neonatus dengan pneumonia memiliki hemoglobin yang lebih tinggi. ${ }^{15}$ Berdasarkan penelitian dari Sawsan Mourad, dkk, kadar hemoglobin yang rendah merupakan faktor resiko untuk infeksi saluran pernapasan bawah (pneumonia). ${ }^{16}$

Pada pemeriksaan CRP, didapatkan 20 penderita $(67,86 \%)$ mengalami peningkatan. Sisanya 9 penderita $(32,14 \%)$ normal. Sesuai dengan kepustakaan yang ada, CRP cenderung meningkat dikarenakan adanya infeksi. ${ }^{17}$ Biasanya kadar CRP lebih rendah pada infeksi virus dan bakteri superfisialis daripada infeksi bakteri profunda. Mesikupun demikian, secara umum CRP belum terbukti secara konklusif dapat membedakan antara infeksi virus dan bakteri. ${ }^{11}$

Rasio netrofil muda dan neutrofil total (rasio IT) adalah perbandingan jumlah sel neutrofil muda dan neutrofil total. Dari hasil yang didapatkan pada IT rasio $>0,2$ yaitu $29(45,31 \%)$, sedangkan $<0,2$ yaitu 35 (54,69\%). Dimana kasus paling banyak yaitu <0,2. Berdasarkan teori neutrofil merupakan mekanisme pertahanan penting terhadap infeksi bakteri, infeksi akan menyebabkan pelepasan neutrofil ke dalam sirkulasi sehingga terjadi peningkatan jumlah neutrofil dalam waktu cepat, sementara cadangan neutrofil neonatus dalam sumsum tulang lebih kecil dari pada orang dewasa dalam keadaan sepsis akan cepat habis. Penurunan jumlah dan fungsi neutrofil akan menyebabkan keadaan immunocompromised sehingga neonatus rentan terhadap infeksi. ${ }^{18}$

Untuk gejala klinis pneumonia neonatus, takipnea merupakan gejala klinis 
yang paling banyak ditemukan dalam penelitian ini yaitu sebanyak $62(96.87 \%)$, diikuti dengan letargi $56(87,5 \%)$, napas cuping hidung $52(81,25 \%)$, retraksi 35 $(54,68 \%)$, demam $37(57,81 \% \%)$, takikardi $12(18,75 \%)$, perut kembung $5(7,81 \%)$, apnea $3(4,69 \%)$ dan sianosis $2(3,12 \%)$. Berdasarkan kepustakaan yang ada, dimana untuk mendiagnosis pneumonia neonatus ditemukan gejala klinis takipnea (>60 x/menit). Kemudian diikuti dengan gejala klinis napas cuping hidung, retraksi, takikardi, sianosis dan apnea. Selain itu juga ada letargi, demam, dan perut kembung. ${ }^{11,17}$

Dari hasil data yang didapatkan, pada kasus pneumonia neonatus untuk pengobatan pada pasien yang sembuh paling banyak menggunakan linea pertama kombinasi (amoxycillin+gentamisin) yaitu $11(45,83 \%)$. Diikuti dengan pengobatan linea kedua kombinasi (ceftazidime+amikasin), yaitu $8(33,33 \%)$. Selanjutnya linea ketiga (meropenem) yang paling sedikit digunakan yaitu 1 $(4,17 \%)$. Dan ada juga pengobatan lain yaitu kombinasi dari masing-masing linea I dan II (ceftazidime+gentamisin) dengan jumlah 4 kasus $(16,67 \%)$.

Hasil data yang didapatkan pada kasus pneumonia neonatus paling banyak ditemukan dengan keadaan yang sembuh mencapai, yakni 34 kasus $(53,12 \%)$, penderita dengan keadaan belum sembuh mencapai 27 kasus (42,19\%), sedangkan penderita yang meninggal yaitu 3 kasus $(4,69 \%)$. WHO memperkirakan 1 dari 3 kematian bayi baru lahir di akibatkan karena pneumonia. ${ }^{19}$ Dalam penelitian sebelumnya, menemukan angka kematian yang didapatkan hanya 2 kasus (4\%) dari neonatus yang menderita pneumonia. ${ }^{13}$

\section{KESIMPULAN}

Telah dilakukan penelitian untuk mencari data-data mengenai profil pneumonia neonatus yang dirawat di Sub Bagian Neonatologi RSUP. Prof. Dr. R. D
Kandou Manado periode oktober 2010september 2012, maka disimpulkan

Pada penelitian ini, pneumonia neonatus paling banyak ditemukan pada onset awal (0-7 hari). Pada leukosit ditemukan paling banyak normal dan sedikit peningkatan. Sementara pada trombosit ditemukan paling banyak dalam batas normal dan kedua terbanyak yaitu terjadi penurunan trombosit, dan pada hemoglobin terbanyak ditemukan peningkatan Hemoglobin.

Pada pemeriksaan CRP didapatkan hasilnya paling banyak mengalami peningkatan. Selanjutnya pada pemeriksaan Rasio imatur dan neutrofil total (Rasio IT) yang paling banyak ditemukan $<0,2$.

Gejala klinis takipnea merupakan salah satu gejala klinis terbanyak pada neonatus yang menderita pneumonia. Penderita pneumonia neonatus banyak yang sembuh dengan menggunakan pengobatan linea pertama kombinasi amoxycillin+gentasmisin. Angka kematian yang didapatkan dari neonatus yang menderita pneumonia sebesar $4,69 \%$.

\section{SARAN}

Setelah melakukan penelitian ini, maka ada beberapa hal yang perlu diusulkan yaitu perlunya penelitian lebih lanjut mengenai profil pneumonia neonatus, pengisian rekam medik sebaiknya diisi dengan lengkap, sebaiknya penyimpanan data rekam medik dilakukan secara komputerisasi agar mempermudah dalam pencarian data dikemudian hari.

\section{UCAPAN TERIMA KASIH}

Diberikan kepada Prof. Dr. dr. Adrian Umboh, SpA (K) dan dr. Johnny Rompis, SpA selaku penguji I dan penguji II dan kepada semua pihak baik secara langsung maupun tidak langsung telah menumbuhkan ide atau gagasan pada penulis sehingga penulis dapat menyelesaikan artikel ini. 


\section{DAFTAR PUSTAKA}

1. Muktasim A. Hubungan antara status gizi dengan lama rawat inap pasien pneumonia balita di RSUD DR. Moewardi Surakarta. Naskah publikasi pada Fakultas Kedokteran Universitas Muhammadiyah, Surakarta. 2012.

2. Nasution K, dkk. Infeksi saluran napas akut pada balita di daerah urban Jakarta. Sari Pediatri. 2009;11 (4) : 223.

3. Kurniawan Y, Indriyani S.A.K. Karakteristik pasien pneumonia di ruang rawat inap anak rumah sakit umum provinsi nusa tenggara barat. CKD-191. 2012;39 (3): 196.

4. Sinaga Lenni A. F. S., Suhartono, Hanani Y. Analisis kondisi rumah sebagai faktor risiko kejadian pneumonia pada balita di wilayah puskesmas Sentosa Baru Kota Medan Tahun 2008. Kesehatan lingkungan indonesia. 2011;8 (1): 26.

5. Choudhury A. M, Nargis S, Mollah A. H, Kabir L. M, Sarkar R. N. Determination of risk factors of neonatal pneumonia. Mymensingh Med J. 2010; 19 (3) : 323.

6. Caserta M. T. Neonatal pneumonia. The Merck manual. 2009. Avaible from:

www.merckmanuals.com/profesional/ pediatrics/infections_in_neonates/neon atal_pneumonia.html. Diakses 21 oktober 2012

7. Henning PA. Neonatal pneumonia. Departement of paediatrics and child health. 2007; 11 (4) : 16.

8. Speer M. E. Neonatal penumonia. Wolters Kluwer Health. 2011. Avaible from:

46.4.230.144/web/UpToDate.v19.2/co ntens/f32/5/32947.htm. Diakses 21 oktober 2012

9. Zaidi A. K. M, Ganatra H. A, Syed S, Cousens S, Lee A. CC, Black R, dkk. Effect of case management on neonatal mortality due to sepsis and pneumonia. BMC Public Health. 2011;11 (3): 2.
10. Duke T. Neonatal pneumonia in developing countries. Arch Dis Child Fetal Neonatal. 2005; 90 (3) : F211.

11. Said M. Pneumonia. In: Rahajoe NN, Supriyatno B, Setyanto DB, penyunting. Buku Ajar Respirologi Anak. Edisi ke-1. Jakarta: Badan Penerbit Ikatan Dokter Anak Indonesia; 2012.p. 352-63.

12. Said M. Tepatkah Mendiagnosis Pneumonia Berdasarkan Hasil pemeriksaan radiologis Semata?. Manajemen Kasus Respiratorik Anak Dalam Prakek Sehari-hari, Cetakan Kedua. Yayasan Penyantun Anak Asma Indonesia SUDDHARAPRANA.; 2007.p. 86.

13. IB Mahendra, I Wayan Retayasa, I Made Kardana. Risk of early onset pneumonia in neonates with abnormal gastric respirate. Paediatrica Indonesiana. 2008;48 (2).

14. Etika R. Gangguan hemostasis pada bayi baru lahir. Dalam: Kosim MS, Yunanto A, Dewi R, Sarosa GI, Usman A, penyunting. Buku Ajar Neonatologi. Edisi pertama, cetakan ketiga; 2012.h. 195.

15. F. Guven, N. Uygur Kulcu, S. Degirmenci, E. Sari, TA Sabuncu, A. Say. Mean platelet volume (MPV) in neonatal pneumonia. 2012. Avaible from:

http://www.kenes.com/espid2012/abst racts/pdf/286.pdf. Diakses 2 Februari 2013.

16. Sawsan Mourad, Mariam Rajab, Aouni Alameddine, Mohammad Fares, Fouad Ziade, Bassem Abou Merhi. Hemoglobin level as a risk factor for lower respiratory tract infection in Lebanese children. North American Journal of Medical Sciences. 2010:2 (10).

17. Prober C. G. Pneumonia pada neonatus. In: Wahab A. S, editor. Nelson Ilmu Kesehatan Anak. Edisi 15 volume 1. Jakarta. Penerbit Buku Kedokteran EGC; 2012.p. 664-66. 
18. Budhiarso H. Rasio imatur/total neutrofil (I/T) pada sediaan hapus darah tepi sebagai petanda dini sepsis bakterial pada anak. Tesis pada Fakultas Kedokteran Universitas Diponegoro, Semarang. 2000.
19. Roger G. Faix. Congenital pneumonia. Medscape Reference. 2011. Avaible from:

http://emedicine.medscape.com/article 1978865-overview\#a0156. Diakses 9 Maret

2013. 